\title{
World Heritage Beech Forests and Regional Socio-Economic Policy at the Slovak-Ukrainian Border
}

\author{
Jaroslav Solár*, Marián Janiga \\ Institute of High Mountain Biology, University of Zilina, Tatranska Javorina, Slovakia Republic
}

Received: 28 January 2019

Accepted: 28 March 2019

\begin{abstract}
The trilateral biosphere reserve in the Eastern Carpathians borders Poland, Slovakia and Ukraine and represents a key model for conserving biological diversity with respect to socio-economic and sustainable development. It is the regional representative of much diversity (language, history, culture, legal framework, and land use and management), and ecological studies are more accessible than data on the mutual effect of nature conservation on the local economy. Our study compares demography, land use, revenue of local stakeholders and the development of eco-tourism using data from the Slovakian and Ukrainian UNESCO World Heritage regions, where both Slovak and Ukrainian stakeholders profit mainly from the forestry industry, though additional but small incomes are derived from local recreation. Incomes from tourism are higher in Ukraine than in Slovakia, while in Slovakia significantly higher income comes in from local taxes than in Ukraine. These factors lead to depopulation (especially of young people) and marginalization of nature conservancy in the region. The forestry industry, with few and less sophisticated job opportunities, and a generally negative impact on the environment (intensive logging, soil erosion, etc.), casually suppresses the creation and development of eco-tourism essentials to the region. To mitigate this effect, this study suggests several steps toward the development of eco-tourism in the Eastern Carpathians-Poloniny region.
\end{abstract}

Keywords: demography, local economy, land use, UNESCO World Heritage, biosphere reserve, Eastern Carpathian Mountains

\section{Introduction}

In the Eastern Carpathian Mountains, UNESCO (Man and the Biosphere Programme - MaB) designed the first trilateral biosphere reserve in the world on the borders of Slovakia, Poland and Ukraine in 1998. The

*e-mail: solar@uniza.sk
East Carpathian Biosphere Reserve (ECBR) was initially designed (1992) as a transboundary reserve combining the Polish Bieszczady National Park (BNP) and Slovak East Carpathians Protected Landscape Area (ECPLa). In 1997, Poloniny National Park (NPP) was established, and in 1998 the trilateral biosphere reserve was created and extended to include the Ukrainian Stuzhytsia Regional Landscape Park as well as Uzhansky National Nature Park (UNNP) that was established in Ukraine in $1999[1]$. 
Currently, the ECBR is divided by the political borders of the European Union (Schengen zone), but throughout history the state borders in this region have often changed; mainly due to First and Second World War events. The ECBR is currently populated by a mixture of ethnic groups including Slovaks, Ukrainians, Poles, Jews and Romani, but development of the landscape was intensively influenced by shepherds and peasants known as Ruthenians during the Wallachian colonization of the $15^{\text {th }}$ and $16^{\text {th }}$ centuries. Agricultural activity along with long-term utilization of mountain meadows and pastures (known as poloniny) led to the development of unique, species-rich mountain plant communities. Although there was continuous exploitation of the region, some forest stands in less accessible areas have preserved their primeval character [2]. The cultural heritage of this group, including sacral wooden architecture dating back to the $17^{\text {th }}$ century, has also been preserved.

The Carpathians are considered one of the major diversity hotspots of Europe [3] and contain one of the largest areas of primeval European beech (Fagus sylvatica L.) forest. This forest represents an outstanding example of undisturbed, complex temperate forest, and contains an invaluable genetic reservoir of beech and many other species dependent on the forest habitat [4]. Generally, old-growth forests are invaluable sources of biodiversity and have a high ecological value [5]. Therefore, these rare primeval beech stands have come under World Heritage protection as "Ancient and Primeval Beech forests of the Carpathians and other Regions of Europe" [4].

Impacts of World Wars I and II as well as the division of the region along state boundaries has had an effect on the development of society in each part of the ECBR (Slovakia, Poland and Ukraine). For example, the Polish part of the territory has remained a deserted and prohibited zone as previous inhabitants of Ukrainian origin were deported under the communist regime [6]. In Slovakia, social and political changes led to significant depopulation in the 1960s and 1970s, mainly due to collectivization. Many small farmers were forced to relocate to work in nearby urban centres with expanding industries [7]. In the 1980s, in addition to postwar reconstruction and other socialist construction projects, 3,500 inhabitants were resettled from seven communities to construct the large Starina Water Reservoir [8]. The Ukrainian part of the region was comparatively less affected by postwar reconstruction and socialist construction of the time, but was later impacted by the transition to a market economy, which encouraged mass migration of young people in search of employment opportunities $[6,9,10]$.

From a historical perspective, clear differences in population dynamics, land ownership, land use and conservancy guided by national legislation exist in the ECBR transboundary region [11]. These differences lead to many complications impacting cooperation among stakeholders, state authorities, and communities in the Poloniny region [11-16]. Bihun et al. [16] described cooperation among affected stakeholders as fragmentary, poorly planned and uncoordinated over the last 10 years, mainly in Ukraine's protected areas. Following the detailed collection of socioeconomic and natural resource data from the Slovakian part of ECBR, we suggested a model of sustainable development of the region based on diversification from forestry to an eco-tourism economy [10, 17-19]. The current projects of the State Nature Conservancy of the Slovak Republic (partly supported by the Slovak-Swiss Cooperation Programme and Norway grants) enabled cooperation between Slovakian and Ukrainian authorities. This bilateral cooperation allowed us to compare socioeconomic characteristics of villages located in the Slovak National Park Poloniny (NPP) and Ukrainian Uzhansky National Nature Park (UNNP). The results are presented in this study, whose aim is a comparison of the demography, land use and revenues of local stakeholders in the context of UNESCO natural heritage protected areas and development of eco-tourism in the region.

Our study does not develop theories regarding regional sustainable development. Rather, it focuses on analyzing existing data on regional development and natural resources in the biosphere reserve valuable region. The indicators for this study were chosen based on the availability of local economy quantitative data and multivariate statistics. Thus, our study tries to fill the gap between research concentrating on visitors' motives and local economic studies by concentrating on a range of indicators for regional sustainable development.

\section{Methods}

\section{Study Area}

Our study area included two national parks and their settlements on the border of Slovakia and Ukraine (Fig. 1). We focused on the East Carpathian Biosphere Reserve, and specifically the National Park Poloniny in Slovakia and Uzhansky National Nature Park in Ukraine, as our interest was the comparison of human population livelihoods in the transboundary region in the context of nature conservation.

National Park Poloniny (NPP) covers an area of 29,805 ha. Settlements in NPP involved in the study were: Stakčín, Runina, Zboj, Nová Sedlica, Topol'a, Príslop, Ruský Potok, Jalová, Kolbasov and Uličské Krivé. Uzhansky National Nature Park (UNNP) was established in 1999 on the basis of Stuzhytsia Regional Landscape Park (14,665 ha). The total area of the current UNNP is 39,159 ha. Settlements studied in this park included: Verkhovyna-Bystra, Vyshka, Volosyanka (and Luh), Zabrid, Zahorb (and Zhornava), Kostryna, Lubnya, Sil' (and Domaskyn), Stavne, Strychava (and Knyahynya), Stuzhytsya and Uzhok. 


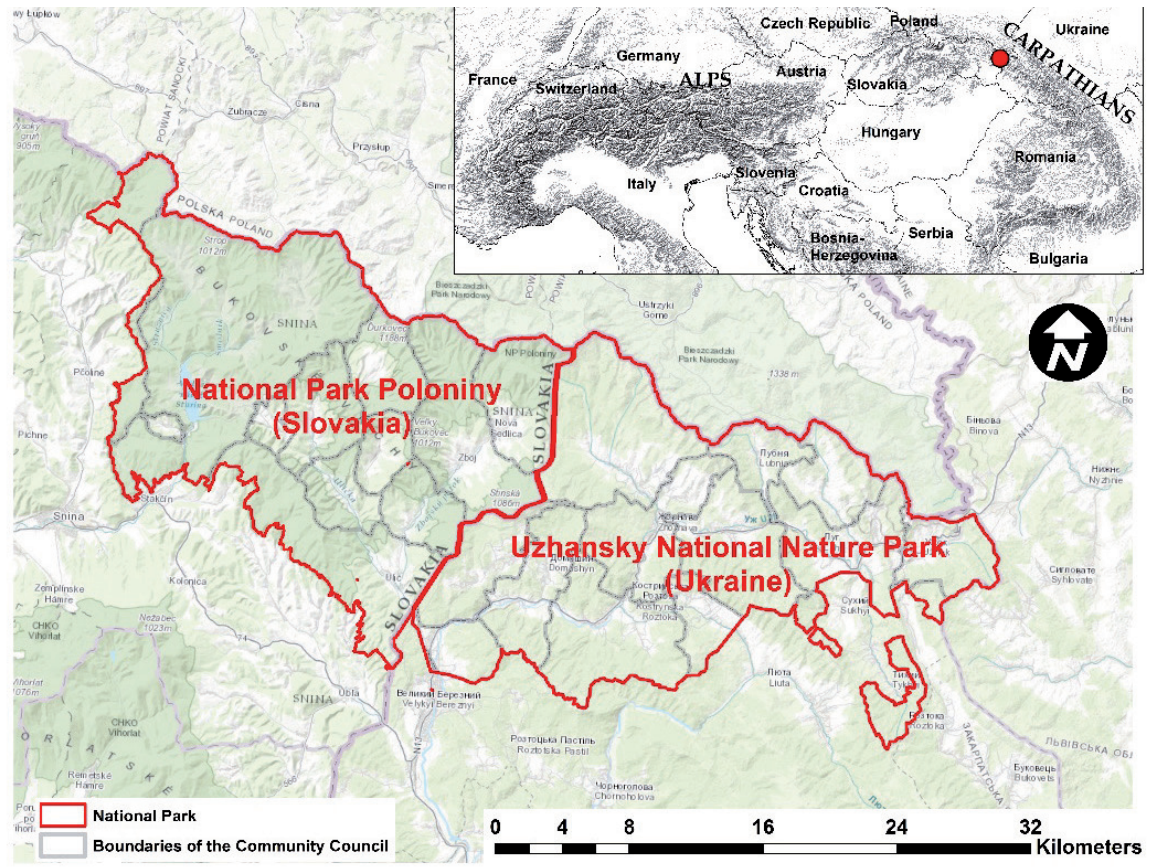

Fig. 1. Study area: National Park Poloniny (NPP) in Slovakia and Uzhansky National Nature Park (UNNP) in Ukraine.

\section{Data Collection}

The cadastral areas of individual settlements represented the basic units of our study. The following groups of data were collected for each cadastre:

Land cover: On the Ukrainian side of the park, land cover was evaluated using GIS and performed in ArcGis 10 software using orthophoto maps from DigitalGlobe. On the Slovak side we used land cover data from the Land Registry Portal of the Slovak Republic [20] and for maps we used Corinne land cover 2012 [21].

Demography (population size, sex ratio): Data was obtained from a questionnaire survey. In Ukraine, the survey was conducted in cooperation with community councils in the UNNP and their mayors in May 2016. The data were validated by comparing information provided by the Department of Statistics in the Zakarpattya region [22]. In Slovakia, the survey was conducted in cooperation with municipalities in the NPP and their mayors in 2014. The data were validated by comparing information from the Statistical Office of the Slovak Republic [23].

We collected data on revenue gained from the extraction of forest products, taxes, recreation and water services. To calculate forestry revenues on the Slovak side, we multiplied data on timber harvesting (according to LGIS - the Forest Geographic Informatics System [24]) by the average price (40 EUR) of timber as specified by the State Forests of Slovak Republic enterprise. In Ukraine, forestry revenues were calculated according to a report titled, "The program of economic and social development of the area of Velykyi Bereznyi District 2017" [25]. In 2016, total logging in the district was $53,000 \mathrm{~m}^{3}$ of wood over a period of 9 months. Two companies in the region are primarily interested in wood harvesting: Velykobereznyansky Forestry and Uzhansky National Nature Park. Velykobereznyansky Forestry sold $15,200 \mathrm{~m}^{3}$ of wood in 2016 , which means that approximately $55,400 \mathrm{~m}^{3}$ of the wood sold was logged in Uzhansky National Nature Park. This number was divided by the area of forest in cadasters of settlements and then multiplied by the price (40 EUR) of wood per square meter.

Tax revenues were calculated using a survey. In Ukraine, we had to use a more complicated approach to estimate tax revenues due to lack of data provided by community councils in the UNNP and their mayors. Approximate tax revenues collected from forest land and from agricultural land were calculated using municipal data. Total tax revenues from land owners were estimated using the taxes from agricultural land (area of arable land and grassland) and forest land in appropriate cadastres of settlements. Tourism revenues represent revenues from visitation (accommodation and food). The amount of money spent for food was calculated using the number of visitors to each settlement multiplied by a minimum of 3 EUR per person paid for lunch. To calculate accommodation revenues we used information on capacity and average price of accommodation (10 EUR) in each settlement (data from web pages). Tourism revenues were computed according to the formula:

$$
\operatorname{Tr}=(v * f)+(b * p * d * u)
$$

...where $\operatorname{Tr}$ is Tourism revenues; $\mathrm{v}$ is estimated number of visitors per year; $\mathrm{f}$ is money spent for daily food (estimation at 3 EUR per person); b is number of beds; $p$ is average price (10 EUR); $d$ is days per year (365); 
and $\mathrm{u}$ is estimated percentage degree of capacity utilization of local touristic areas according to regional reports $(7.1 \%)$.

Data obtained from a survey were also used to estimate water revenues. These revenues were only calculated for villages connected to the public water supply and the following formula was used:

$$
\mathrm{Wr}=((\mathrm{n} * \mathrm{~s} * \mathrm{~d}) / 1,000) * \mathrm{p}
$$

... where $\mathrm{Wr}$ is water revenues; $\mathrm{n}$ is number of people connected to fresh water supply; $\mathrm{s}$ is specific water consumption (12.48 1/day-1/person in 2011 - according to the World Bank); d is days per year (365); $\mathrm{p}$ is price per $\mathrm{m}^{3}$ of the fresh water (1.57 EUR annual price of freshwater in Slovakia); and exchange rate $28 \mathrm{UAH}=1 \mathrm{EUR}$.

\section{Statistical Analysis}

All collected and computed data were processed to the data matrix, which was standardized and statistically analysed by Statistica 12 software (StatSoft, USA). Except for base statistics (correlation analysis), the Mann-Whitney $U$ test was used to compare the medians of variables, including land cover, demography and revenues in Slovakia and Ukraine. Following this, multivariate statistics methods were used and a principal component analysis (PCA based on correlation) was performed to identify the potential relationships between variables. This analysis uses an orthogonal transformation to convert a set of observations of possibly correlated variables into a set of values of linearly uncorrelated variables called principal components (see Results, Table 1 and Figs 5-6).

\section{Results}

Significant differences $(\mathrm{p}<0.05)$ were found between the Slovakian and Ukrainian regions in the case of land typology (amount of arable land, urban areas). Larger amounts of arable land are found in Ukraine than in Slovakia. Ukrainian people are still very active in agriculture when compared to people who live on the Slovakian side of ECBR (Fig. 2). Significant differences were also found in population variables (sex ratio and natality). Ukrainian settlements are more populated than Slovakian villages on average. Ukrainian settlements have a population range of 500 to 2,000 inhabitants, while Slovak settlements have a population range of 70 to 400 inhabitants. The trend of higher emigration from the countryside to urban centres was more pronounced in Slovakia than in Ukraine (Fig. 3). Significant differences were found in revenues from water resources and taxes in the region, but not in revenues from forest extraction (Fig. 4). Slovak and Ukrainian stakeholders profit from forestry equally, and forestry remains the main source of revenue in both regions. In Ukraine there is a significantly higher income derived from local recreation than in Slovakia, while the revenue gathered from local taxes is significantly higher in Slovakia than in Ukraine (Fig. 4).

Three main effects were observed in both regions (Table 1). First, the most important phenomenon in the region (factor $1,52 \%$ of the total data variance) reflects the mutual interrelationship among the total cadastre area, population size and financial income from taxes or forestry. The regions did not differ in this complex of relationships (Fig. 5). Simply put, larger and more populated areas earned more money from taxes and forestry. The second very important feature which differentiates the Ukrainian and Slovakian regions is described by factor 2 (29\% of total variance; Table 1$)$. In Slovakia, a significantly higher revenue is gathered from taxes and forestry, while significantly less revenue is collected from tourism, than in Ukraine (Fig. 6). The third variance ( $8 \%$ of data variance) is found in revenue collected from tourism in relation to urban areas. In both countries $(\mathrm{F}(1,20)=0.15, \mathrm{p}=0.7)$, income from tourism is higher in urban areas than in the country due to higher visitation numbers.

\section{Discussion}

Although the East Carpathian Biosphere Reserve was established approximately 20 years ago, only limited data currently exists regarding the impact of the reserve on the local economy. More exhaustive studies have been conducted on fauna or flora of the region but few socioeconomic or cultural observations can be found [11]. At the beginning of their conservation history, both regions were so-called landscape protected areas, enjoying a lower intensity of legislative protection than national parks. Establishment of the East Carpathian Biosphere Reserve initiated a new process - the creation of national parks [1] - but with low incorporation of local communities. From this point of view, Poloniny NP remained a typical forestry national park, where the stakeholders profit mainly from forestry [17]. This also is largely the case in the Ukrainian part of the biosphere reserve, though the effect of new income from the development of so-called "mass" tourism is visible. Ukraine only has a few regions where ski resort development is permitted, and the East Carpathians are one of them (see Szulga and Onufriw [26]). From this point of view, the development of the Ukrainian region of the park is more dangerous for the ecosystem than activities on the Slovakian side. Pressure from the forestry industry also tends to increase in relation to increased consumption of firewood. In Ukraine, there is a visible effort by many organisations to use more resources produced from forest biomass. Raslavičius et al. [27] estimate that this resource will represent double the consumption of wood for energy production by 2030. In Slovakia, many national parks and landscapeprotected areas are intensively influenced by forestry 


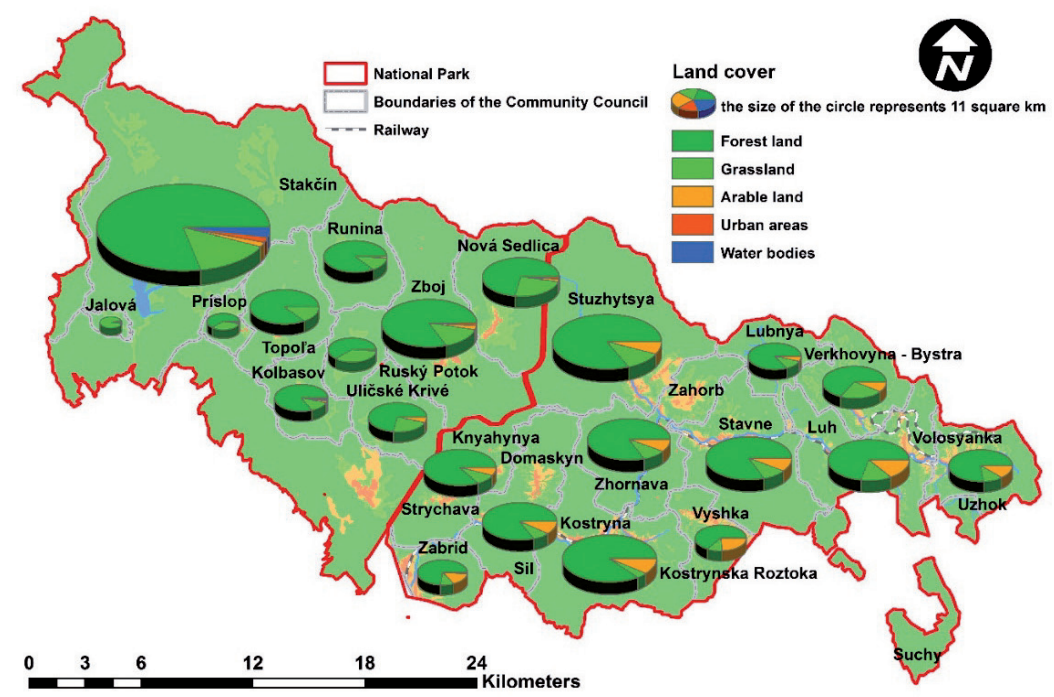

Fig. 2. Comparison of land cover classes for settlements in the NPP and UNNP.

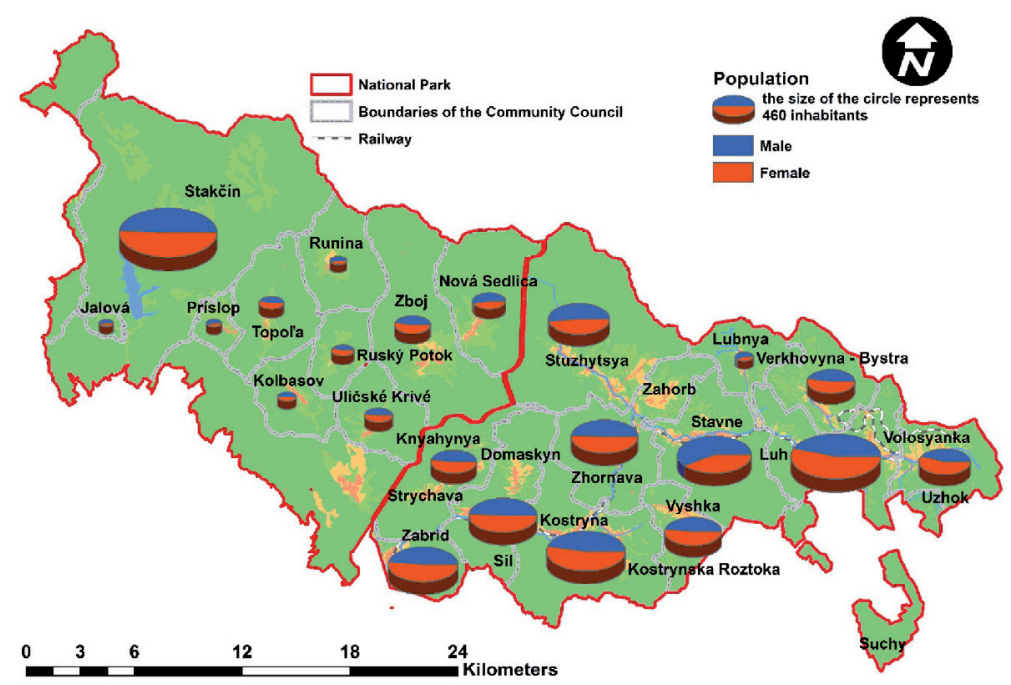

Fig. 3. Comparison of population size for settlements in the NPP and UNNP.

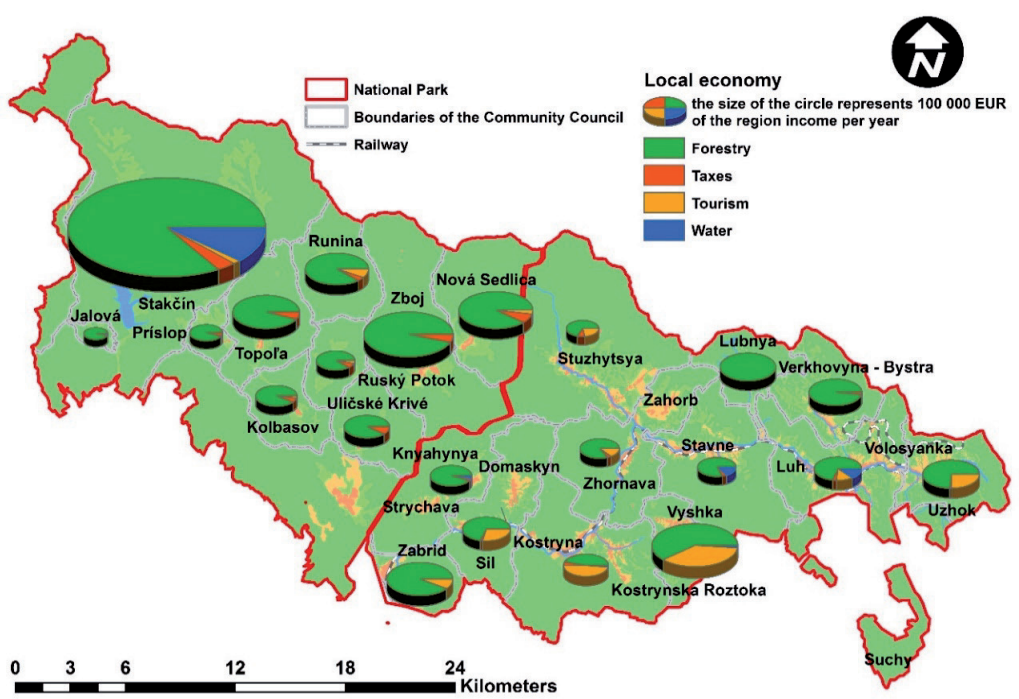

Fig. 4. Comparison of local economy for settlements in the NPP and UNNP. 
Table 1. Eigenvalues of principal component analysis of the socioeconomic relations in the settlements of cross-border UNESCO protected areas (National Park Poloniny in Slovakia and Uzhansky National Nature Park in Ukraine); three main factor coordinates of the original variables are presented.

\begin{tabular}{|c|c|c|c|}
\hline Variables & Factor 1 & Factor 2 & Factor 3 \\
\hline Total area $\left(\mathrm{km}^{2}\right)$ & $-0,302$ & $-0,099$ & $-0,046$ \\
\hline Extravilan $\left(\mathrm{km}^{2}\right)$ & $-0,300$ & $-0,120$ & $-0,042$ \\
\hline Intravilan $\left(\mathrm{km}^{2}\right)$ & $-0,105$ & 0,313 & $-0,062$ \\
\hline Extravilan \% & $-0,012$ & $-0,351$ & 0,414 \\
\hline Intravilan \% & 0,012 & 0,351 & $-0,414$ \\
\hline Arable land $\left(\mathrm{km}^{2}\right)$ & $-0,167$ & 0,328 & 0,116 \\
\hline Forest land $\left(\mathrm{km}^{2}\right)$ & $-0,299$ & $-0,093$ & $-0,027$ \\
\hline Grassland $\left(\mathrm{km}^{2}\right)$ & $-0,269$ & $-0,179$ & $-0,126$ \\
\hline Urban areas $\left(\mathrm{km}^{2}\right)$ & $-0,270$ & $-0,195$ & $-0,169$ \\
\hline Water bodies $\left(\mathrm{km}^{2}\right)$ & $-0,281$ & $-0,158$ & $-0,145$ \\
\hline Population & $-0,271$ & 0,185 & 0,173 \\
\hline Density per $\mathrm{km}^{2}$ & $-0,052$ & $\mathbf{0 , 3 3 6}$ & 0,080 \\
\hline Male & $-0,274$ & 0,180 & 0,167 \\
\hline Female & $-0,271$ & 0,189 & 0,163 \\
\hline Natality & $-0,233$ & 0,186 & 0,286 \\
\hline Mortality & $-0,218$ & 0,172 & 0,278 \\
\hline Tourism EUR & $-0,052$ & 0,252 & $-0,474$ \\
\hline Tax EUR & $-0,259$ & $-0,220$ & $-0,168$ \\
\hline Forestry EUR & $-0,264$ & $-0,170$ & $-0,258$ \\
\hline Total variance \% & 52,05 & 29,59 & 8,14 \\
\hline
\end{tabular}

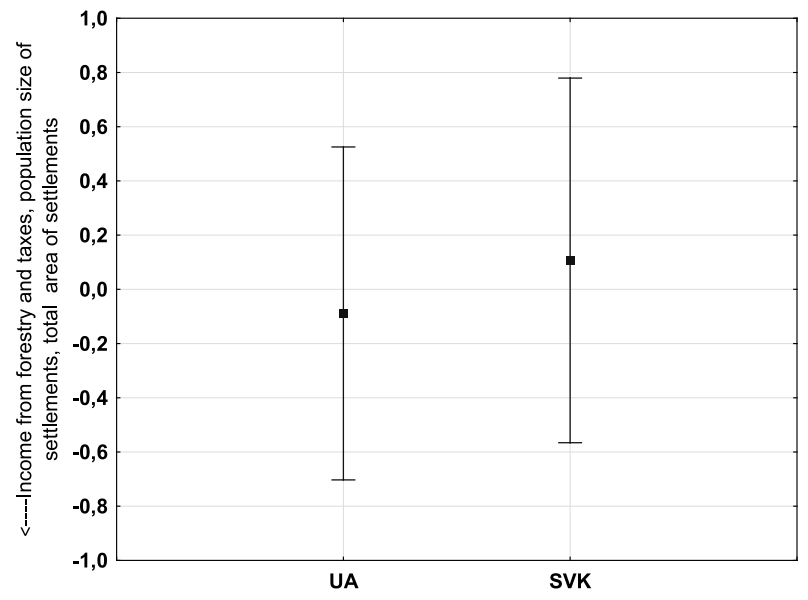

Fig. 5. Mutual interrelation among cadaster size, population size and the main source of income (forestry, taxes) is a dominant typology of socio-economies in both regions; points denote means of factor scores (factor 1) with 0.95 confidence limits; the regions do not differ: one-way ANOVA of factor loading scores $-\mathrm{F}(1,20)=0.2, \mathrm{p}=0.66$

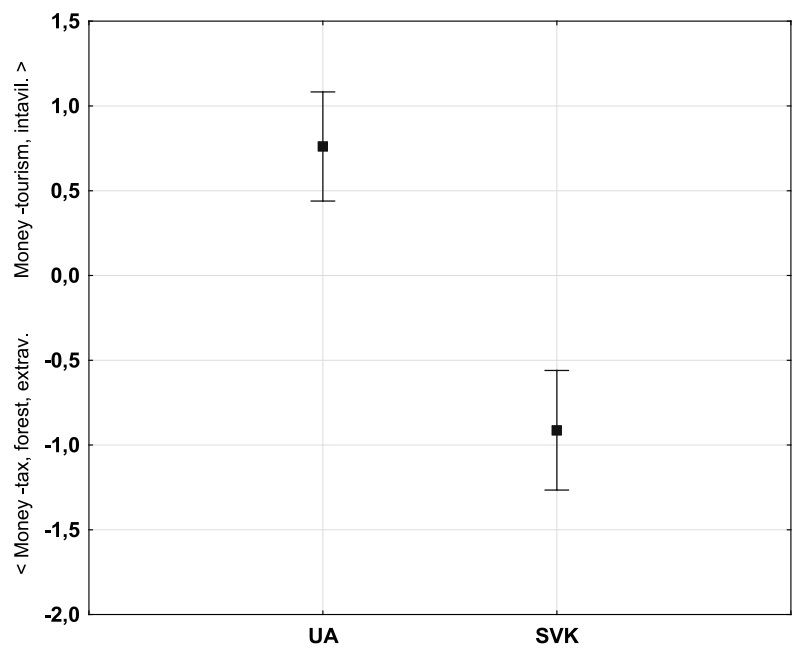

Fig. 6. Difference in the trends: revenues from tax and forestry versus revenues from recreation; means of factor scores (factor 2) with 0.95 confidence limits; one-way ANOVA of factor loading scores: $\mathrm{F}(1,20)=53.4, \mathrm{p}=0.000$.

[17]. The forestry sector exerts a strong influence, as many households are heated by wood due to the high price of gas (even while Slovakia has good gas infrastructure). In Slovakia, the pulp and paper industry is one of the largest consumers of forestry products. The pulp and paper factory in Ružomberok alone consumes approximately one third of wood produced in the Poloniny region and $40 \%$ of broad-leafed trees harvested in the country [28-30]. Therefore, many experts expect excessive logging to be an issue in the future [31-33].

Threats to environments in Eastern European countries where the high-quality assessments were conducted include: unsolved ownership (Croatia, Serbia, Bulgaria, Romania); forest management and logging (Slovakia, Romania, the Czech Republic); poaching (Slovakia, Romania); land use changes - manifested both by land abandonment followed by overgrowth and succession and by the intensification of land/resource use (Romania, Slovakia, Czech Republic, Slovenia, Croatia, Albania); infrastructure development and building (Bulgaria, Slovakia, Romania); uncontrolled tourism development (Bulgaria, Albania, Slovakia, Romania, Serbia, Slovenia) and waste disposal [34]. In many Slovakian NPs, the most prevalent issue is the increasing dominance of commercial forest use [35]. Daily, tourists can see commercial logging taking place [36] and are very aware of this conflict between managed and protected forest areas [37]. In response, the forestry industry suppresses the creation and development of the eco-tourism essential for regional development in protected areas.

Recently, there has been a noticeable increase of individuals in Slovakia promoting non-commercial usage of forests [38]. However, even the establishment of the biosphere reserves and Natural World Heritage localities was a process partly driven by political motivations and did not contribute discernibly to the daily lives of 
local inhabitants [39]. Many people living next to these forests sensitively monitor changes. Currently, more than 60000 people have signed the "We are the forest" petition against logging in the forests of Slovakia. The campaign has over a million views on Facebook - a high achievement considering the relatively modest population of 5.5 million Slovaks. Moreover, there is a causality between population decrease in small villages and increased activity by the forestry industry $[10,17]$. While logging does add some jobs in a given village, young people usually migrate to larger urban areas for access to higher-paid and more sophisticated employment opportunities. This increased emigration is a major concern in the ECBR region of Slovakia [15, 40, 41]. The emigration trend is less noticeable in the ECBR mountain region of Ukraine, where local people are still active in agriculture and small business [42]. Similarly, while land abandonment is prevalent within the Polish ECBR region [43], demographically, the region maintains a nearly stable population and age structure, dominated by working-age individuals [44]. This is likely attributable to tourism and job opportunities.

On the Polish side of the ECBR, tourism is very well developed as the Bieszczady Mountains (Poloniny) are exceptionally popular with Polish tourists [45]. Prędki [46] sees an estimated 500,000 visitors per year from within Poland alone (relevant data on the number of visitors from Slovakia or Ukraine does not exist). Bieszczady National Park is $292 \mathrm{~km}^{2}$ with more than $130 \mathrm{~km}\left(0.45 \mathrm{~km} / \mathrm{km}^{2}\right)$ of developed pathways for recreational use. Uzhansky National Park in Ukraine has a land area of $391.6 \mathrm{~km}^{2}$ with $90 \mathrm{~km}$ $\left(0.23 \mathrm{~km} / \mathrm{km}^{2}\right)$ of developed trails. Poloniny National Park in Slovakia has a total area of $407.8 \mathrm{~km}^{2}$ with $121 \mathrm{~km} \quad\left(0.29 \mathrm{~km} / \mathrm{km}^{2}\right)$ of developed trails. Administration of the Slovak Poloniny NP has traditionally relied on support from the government, but the costs of conservation, while relatively low, still represent a significant amount for a government with other priorities to manage. Without assistance from external European funds, revenue from government sources will fall short, and the need to balance environmental considerations with continued pressure from economic drivers (such as the forestry industry) is becoming more difficult to manage [45, 47, 48].

Janiga et al. [17] underline that it is not sufficient to have the right numbers of protected areas in the right places, it is also necessary to ensure that their governance is able to manage them in an effective manner and produce the desired outcomes. There is an urgent need to find ways for national parks to generate sufficient funds to make a contribution to their operating costs. Graham et al. [49] suggested that there are several options for complete or partial government management. One is a park management function integrated into another agency, such as a wildlife agency, which proved to be very ineffective for Slovakian parks. A second is a park agency as a distinct unit within a larger government agency. A third is a separate public parks agency that reports directly to a cabinet member. A fourth is a parastatal, a semi-autonomous body reporting to a board of members of the park. The government typically appoints these board members. This paper suggests that this fourth approach, as per our previous analyses [17], is the most suitable for Slovakian national parks.

In Slovakia, directories of NPs are not statutory bodies, which means that legal restrictions prevent NPs from generating and spending their own incomes and require any revenues raised by NPs to be returned to the national exchequer. Restrictions of this type discourage staff of NPs from seeking ways to supplement their funding with other sources of income. In a previous study [17], we urgently suggested that national parks should be administered on an individual basis, separate from the central statutory body (the state nature protection agency, located in Banská Bystrica). A model of an eco-tourism where the park leads environmental conservation activities in addition to managing regional development [17] would be welcome in these regions of Slovakia and Ukraine in order to protect natural and culture heritage. We also suggested that strengthening the legislative status of Poloniny NP, adopting zonation as a key management tool for PAs [50], and strengthening fruitful and positive cooperation between local communities would be extremely beneficial [51]. It is also particularly important to ensure the diversity of income sources as a tool to improve the administration of PAs. The administrative budget for national parks should be comprised of income from the state budget, income from annual stakeholder revenues and income from the park's own business activities and projects funded by various grants [17].

The main market segment that offers revenue generation potential in the Poloniny region is ecotourism, which has been recognized as the fastest growing sector within the international tourism market since the 1980s, and protected areas represent a major draw for this economic sector [52, 53]. A timely discussion is how eco-tourism can be steered such that recreational tourism values are realized while at the same time ensuring that endangered species and their habitats are conserved. In our previous studies, we suggested steps to the development of eco-tourism in the Poloniny region $[10,17]$. Firstly, market-targeted products should be developed and offered as a startup of the administration of the reformed Poloniny NP. These products are necessary for a protected area to be successful in attracting a regular flow of tourists. Secondly, a professional guides group would be created and given responsibility for the region of the national park. We estimate that the administrative body of the NP has sufficient human and financial resources to cover the start-up in the region. Thirdly, the provision of tourism services represents an alternative and supplementary way for communities to generate revenue from biological diversity, education and empowerment, and maintenance of sustainable practices, by funding the development of infrastructure and services. Without 
market demand, tourism has little to offer a protected area. While protected areas are rife with opportunities for tourism ventures, it is generally the commercial tourism sector that provides the necessary services, including accommodation and transportation, for tourists to visit protected areas. Fourth, to be successful at managing tourism revenues, the NP should develop and gradually implement new effective tourism management plans that integrate tourism alongside conservation management priorities and establish limits on the scale and types of tourism permitted. This will require the effective coordination of the policy, legal, tourism and conservation concerns of Poloniny NP as well as the incorporation of local communities.

\section{Conclusions}

Establishment of the East Carpathian Biosphere Reserve and national parks in the transboundary region of Slovakia, Ukraine and Poland were largely actioned by state institutions with little integration from local communities in the decision-making process. This onesided approach has led to a general low acceptance of nature conservation by the local population. To date, the local economy is largely forestry-based, but there has recently been a noticeable increase in public sentiment promoting non-commercial usage of forests. The eco-tourism market is growing quickly, but the current administration structure of natural parks is not flexible and they are not perceived to contribute quantitatively to the daily lives of most local people. The forestry industry, as the dominant economic actor in the region, also works to suppress the development of eco-tourism as an effort to diversify the economy in the region. Some forestry activities are contraindicative to sustainable development and the conservation of biodiversity - especially where rare natural habitats and vulnerable species are present. Forestry brings a limited number of jobs to the local economy, so young people tend to migrate to larger urban areas in search of other opportunities.

An eco-tourism model where the park leads conservation activities in addition to driving regional development would be welcomed and supported in these parts of Slovakia and Ukraine to help protect natural and culture heritage. Taking this into consideration, we recommend that the legislative status of NPs be strengthened, that zonation be adopted as a key management tool for PAs and that the role of the central statutory agency be delimited. It is also extremely important to ensure diversity of financial incomes in the region, which could be an important tool in the continuous improvement of the administration of protected areas. In order to develop eco-tourism in Poloniny, the following steps are essential: development of a market-orientated product as a start-up; development of a professional guiding group; development of market demand; and development and implementation of new, more effective tourism management plans in collaboration with local communities.

\section{Acknowledgements}

This work was supported by a grant from Norway and co-financed by the State Budget of the Slovak Republic in the project "Nature Conservation as an Opportunity for Regional Development" (CBC01012); the operation program "Cross-border cooperation" (SK08) focused on how to "Reduce existing barriers to cross-border cooperation”.

\section{Conflict of Interest}

The authors declare no conflict of interest.

\section{References}

1. KRICSFALUSY V., BUDNIKOV G., LESIO I. Rare and protected plant species of the Uzhansky National Nature Park (Transcarpathia, Ukraine). Thaiszia-Journal of Botany 20 (2), 115, 2010.

2. DYMYTROVA L., NADYEINA O., HOBI M. L., SCHEIDEGGER C. Topographic and forest-stand variables determining epiphytic lichen diversity in the primeval beech forest in the Ukrainian Carpathians. Biodiversity and conservation, 23 (6), 1367, 2014.

3. BÁLINT M., UJVÁROSI L., THEISSINGER K., LEHRIAN S., MÉSZÁROS N., PAULS S.U. The Carpathians as a Major Diversity Hotspot in Europe. In: Zachos F.E. \& J.C. Habel (eds.) Biodiversity Hotspots, Springer-Verlag Berlin Heidelberg, 189, 2011. doi: 10.1007/978-3-642-20992-5 11

4. UNESCO Conference of Committee of the UNESCO World Heritage in New Zealand, Christchurch, June 28, 2007.

5. BRUNET J., FRITZ Ö., RICHNAU G. Biodiversity in European beech forests - a review with recommendations for sustainable forest management. Ecological Bulletins 53 (7), 77, 2010. Available at: http://www.jstor.org/ stable/41442021 (accessed 12/12/17)

6. NIEWIADOMSKI Z. The East Carpathians - the world's first trilateral UNESCO biosphere reserve. In: VASILIJEVIĆ M., PEZOLD T. (eds.), Crossing borders for nature: European examples of transboundary conservation. International Union for Conservation of Nature and Natural Resources, IUCN, Gland, Switzerland, 26, 2011.

7. BEZÁK P., MITCHLEY J. Drivers of change in mountain farming in Slovakia: from socialist collectivisation to the Common Agricultural Policy. Regional environmental change 14 (4), 1343, 2014. doi: 10.1007/s10113-013-0580-x

8. OSZLÁNYI J., HALADA L', GAJDOŠ P., ŽILA P., BEZÁK P. The Consequences of Long-Term Land Use Changes to Agriculture, Grassland Vegetation and Selected Invertebrates in the Marginal Mountain Region of Slovakia. In: Proceedings of the International Conference "Transition to a New Society ". Podgorica: Montenegrin Academy of Sciences and Arts, 405, 2014. 
9. HALADA L', DAVID S., HREŠKO J., KLIMANTOVÁ A., BAČA A., RUSŇÁK T., BURAL M., VADEL L'. Changes in grassland management and plant diversity in a marginal region of the Carpathian Mts. in 1999-2015. Science of the Total Environment, 609, 896, 2017.

10. SOLÁR J., JANIGA M., MARKULJAKOVÁ K. The Socioeconomic and Environmental Effects of Sustainable Development in the Eastern Carpathians, and Protecting its Environment. Polish Journal of Environmental Studies 25 (1), 291, 2016.

11. TAGGART-HODGE T., SCHOON M. The challenges and opportunities of transboundary cooperation through the lens of the East Carpathians Biosphere Reserve. Ecology and Society 21 (4), 16, 2016. http://www.jstor.org/ stable/26270039

12. FALL J.J. Transboundary biosphere reserves: a new framework for cooperation. Environmental Conservation, 26 (4), 252, 1999.

13. OSZLÁNYI J., GRODZIŃSKA K., BADEA O., SHPARYK Y. Nature conservation in Central and Eastern Europe with a special emphasis on the Carpathian Mountains. Environmental Pollution 130 (1), 127, 2004. doi: 10.1016/j.envpol.2003.10.028

14. NIEWIADOMSKI Z. The Carpathians as a region of international co-operation. Europa Regional 12 (4), 168, 2004. Available at: http://nbn-resolving.de/ urn:nbn:de:0168-ssoar-48129-9 (accessed 12/12/17).

15. NIEWIADOMSKI Z. The first trilateral UNESCO-MAB Biosphere Reserve 'East Carpathians' (Poland/Slovakia/ Ukraine). In: STEIN R., HEIL P., TUČEK L. (eds.), Proceedings of the 2004 International Conference and Expert Workshop of Transboundary Biosphere Reserves: Following-up on Seville+5, 2006.

16. BIHUN Y.M., KEETON W.S., STANKIEWICZ O., CERONI M. Transboundary protected areas cooperation in the East Carpathian and Carpathian Biosphere Reserves. World Wide Fund for Nature, Vienna, Austria, 2008. Available at: http://www.uvm.edu/rsenr/wkeeton/pubpdfs/ BihunKeetonStankiewiczCeroni2008ReportWWF.pdf (accessed 12/12/17)

17. JANIGA M., MARKULJAKOVÁ K., MAHÚT O., POGÁNYOVÁ P., KOHÚTOVÁ Z., ŠULAVÍK J., BOHÁČOVÁ A., HERIAN N., IVANIČOVÁ Z., VESELSKÁ M., ŠTEFANCOVÁ D., IŠTOŇA M., TICHÝ P., KVANDA P., MIKOLÁŠ P., GRIGA F., CHOVANCOVÁ S., ADAMOVÁ M., LIŠTIAKOVÁ E., GAŠPERANOVÁ J., KOZÁRIK V., HRUŠKA M., PODRACKÁ M., MASARYK M., NOVISEDLÁKOVÁ J., THOMKOVÁ J., KMECÍK V. KARKOSZKOVÁ D., BUGÁŇ P., ŠUDILA M., RICHTÁRECH P. Revenues of stakeholders in the national parks and landscape protection areas of the Slovak Republic. Oecologia Montana 21 (2), 1, 2012. [In Slovak].

18. SOLÁR J., MARKULJAKOVÁ K., JANIGA M. Study of sustainable development of protected areas in the National Park Poloniny. Emphasis on socioeconomics relation with land use and protections of nature. Baseline Study. Prepared for development of nature conservation and of protected areas in the Slovak Carpathians, Slovak-Swiss Cooperation Programme, 38, 2014.

19. SOLÁR J., JANIGA M., ŠOLTÉS R., KLEMOVÁ GREGUŠKOVÁ E., STOKLASA J. Current biodiversity and hotspots in the primeval beech forest - Poloniny National Park, the Eastern Carpathians (Slovakia). Oecologia Montana 26 (2), 1, 2017.
20. Land Registry Portal of the Slovak Republic 2017. Available at: www.katasterportal.sk (accessed 15/2/17)

21. Corinne land cover maps 2012. Available at: https://land. copernicus.eu/ (accessed 15/2/17)

22. Department of Statistics in Zakarpattya region 2017. Available at: www.uz.ukrstat.gov.ua (accessed 15/2/17)

23. Statistical Office of the Slovak Republic 2017. Available at: www.statistics.sk (accessed 15/2/17)

24. Forest Geographic Informatics System (LGIS) 2017. National Forest Centre. Zvolen. Available at: http:/gis. nlcsk.org/lgis/ (accessed 15/2/17)

25. The program of economic and social development of the area of Velykyi Bereznyi District, Ukraina 75, 2017. Available at: www.velberez.gov.ua/images/doc/138_Progr. ekon.i_coz.rozv.2017.doc (accessed 14/3/17)

26. SZULGA G. ONUFRIW J. Current trends in the development of mountain resorts designed for winter sports in the eastern Carpathians in the chine Chornogory. Przestrzeń i Forma (Space \& Form) 21, 377, 2014.

27. RASLAVIČIUS L, GRZYBEK A., DUBROVIN V. Bioenergy in Ukraine - Possibilities of rural development and opportunities for local communities. Energy Policy 39 (6), 3370, 2011. doi: 10.1016/j.enpol.2011.03.032

28. MŽP SR Increasing the energy efficiency of the cellulose production process at Mondi SCP, a.s., Ružomberok. Available at: http://www.enviroportal.sk/sk\%20SK/ eia/ detail/zvysenie-energetickej-efektivnosti-procesu-vyrobycelulozy-v-mondi-scp (accessed 14/3/17) 2011 [In Slovak].

29. SAŽP State of the Environment Report of the Slovak Republic. Available at: https://www. enviropor tal.sk/ uploads/repor t/vply vy-hospod.pdf (accessed 14/317) 2015 [In Slovak].

30. PAROBEK J., PALUŠ H., KAPUTA V., ŠUPÍN M. Analysis of wood flows in Slovakia. BioResources 9 (4), 6453, 2014.

31. GUBKA A, NIKOLOV CH., GUBKA K., GALKO J., VAKULA J., KUNCA A., LEONTOVYČ R. History, Present and Expected Future of Forests in Slovakia. American Journal of Plant Sciences 4 (3), 711, 2013. doi: 10.4236/ajps.2013.43A090

32. IZAKOVIČOVÁ Z., MIKLÓS L. Biodiversity Protection of the Forest Ecosystems on the Base of Representative Geoecosystems. In: KOULOV B., ZHELEZOV G. (eds.), Sustainable Mountain Regions: Challenges and Perspectives in Southeastern Europe. Springer International Publishing, 151, 2016.

33. GEJDOŠ M., SUCHOMEL J. Potential, prices and resources of raw wood assortments for the pulp and paper industry in central Europe. Key Engineering Materials 688, 210, 2016. doi: 10.4028/www.scientific.net/ KEM.688.210

34. STANCIU E., IONITA A. Governance of Protected Areas in Eastern Europe-overview on different governance types, case studies, and lessons learned. Study commissioned to ProPark, Romania, by the German Federal Agency for Nature Conservation $(\mathrm{BfN}), \mathrm{BfN}-$ Skripten, 2013.

35. POVAŽAN R., GETZNER M., ŠVAJDA J. Value of Ecosystem Services in Mountain National Parks. Case Study of Velká Fatra National Park (Slovakia). Polish Journal of Environmental Studies 23 (5), 1699, 2014.

36. FALŤAN V., BÁNOVSKÝ M., BLAŽEK M. Evaluation of land cover changes after extraordinary windstorm by using the land cover metrics: A case study on the High Tatras foothill. Geografie 116, 156, 2011. 
37. KIŠ K., BRKIĆ M. Inclusion of Public and Concerned Public in Environmental Protection Affairs. First Regional Conference on Environmental, Impact assessment, Zbornik Radova/Proceedings Sekcija 4/Section 4, Sudjelovanje Javnosti/Public participation, September 1821, 2013, Zadar, Croatia, 2014. Available at: http://www. huszpo-konferencija.com/wp-content/uploads/2014/06/ sekcija-4_section-4.pdf\#page=92 (accessed 12/12/17)

38. DOBŠINSKÁ Z., SARVAŠOVÁ Z. Perceptions of Forest owners and the general public on the role of forests in Slovakia. Acta Silvatica et Lignaria Hungarica 12 (1), 23, 2016. doi: 10.1515/aslh-2016-0003

39. NOLTE B. Sustainable Tourism in Biosphere Reserves of East Central European Countries - Case Studies from Slovakia, Hungary and the Czech Republic. In: SIEVANEN T., ERKKONEN J., JOKIMAKI J., SAARINEN J., TUULETIE S., VIRTANEN E. (eds.), Policies, Methods and Tools for Visitor Management. Finish Forest Research Institute, Rovaniemi, 349, 2004.

40. BEZÁK P., HALADA L. Sustainable Management Recommendations to Reduce the Loss of Agricultural Biodiversity in the Mountain Regions of NE Slovakia. Mountain Research and Development 30 (3), 192, 2010. doi: 10.1659/MRD-JOURNAL-D-10-00023.1

41. GALLAY I., GALLAYOVÁ Z. Zarastanie pol'nohospodárskej krajiny Slovenska drevinovou vegetáciou. [Overgrowing of agricultural land in Slovakia by woody vegetation.] Geoinformation 8, 18, 2012. [In Slovak].

42. TSARYK J., KYYAK V., HORBAN I., TSARYK I., RESHETYLO O. Grazing effects on the natural conservation value of pastures in the Carpathians, In: ROTH M., NOBIS R., STETSIUK V., KRUHLOV I. (Eds.), Transformation processes in the Western Ukraine. Concepts for a sustainable land use, Weißensee Verlag, Berlin, 291, 2008.

43. KLICH D., GIELAREK S., ANTOSIEWICZ M. Land cover dynamics in western Bieszczady Mts between $19^{\text {th }}$ and $20^{\text {th }}$ century. Ekologia 32 (1), 95, 2013. doi: 10.2478/ eko-2013-0008

44. CELINSKA-JANOWICZ D., MISZCZUK A., PŁOSZAJ A., SMĘTKOWSKI M. Current Demographical Problems of the Eastern Poland Macroregion. EUROREG Reports and Analyses 5/2010, Warsaw: EUROREG University of Warsaw, 2010.

45. ŚWIGOST A. The transformation of the natural environment of the Polish and Ukrainian Bieszczady mountains due to tourism and other forms of human pressure. Current Issues of Tourism Research 5 (2), 27, 2015.

46. PRĘDKI R. Tourist traffic in the Bieszczady National Park, 2009-2011. Roczniki Bieszczadzkie, 20, 358, Ustrzyki Dolne: Wyd. Impuls., 2012 [In Polish].

47. SVOBODA M., FRAVERB S., JANDA P., BAČE R., ZENÁHLÍKOVÁ J. Natural development and regeneration of a Central European montane spruce forest. Forest Ecology and Management 260, 707, 2010. doi: 10.1016/j. foreco.2010.05.027

48. KNORN J., KUEMMERLE T., RADELOFF V.C., SZABO A., MINDRESCU M., KEETON W.S., ABRUDAN I., GRIFFITHS P., GANCZ V., HOSTERT P. Forest restitution and protected area effectiveness in post-socialist Romania. Biological Conservation 146, 204, 2012. doi: 10.1016/j.biocon.2011.12.020

49. GRAHAM J., AMOS B., PLUMPTRE T.W. Governance principles for protected areas in the $21^{\text {st }}$ century. Institute on Governance, Ottawa, Ontario, Canada, 2003. Available at: https://www.files.ethz.ch/isn/122197/pa_governance2. pdf (accessed 12/12/17)

50. SYNGE H. European Models of Good Practice in Protected Areas, AV+Astoria Druckzentrum, Vienna, 2010.

51. COETZER K.L., WITKOWSKI E.T., ERASMUS B.F. Reviewing Biosphere Reserves globally: effective conservation action or bureaucratic label?. Biological Reviews, 89 (1), 82, 2014.

52. MOORE S.A., WEILER B. Tourism-protected area partnerships: stoking the fires of innovation. Journal of Sustainable Tourism 17 (2), 129, 2009. doi: 10.1080/09669580802582506

53. FENNELL D.A. Ecotourism. Taylor \& Francis, Routledge, London. 2014 